\title{
AZORUBIN-BINDING CAPACITY AND PROTEIN COMPOSITION OF SERUM OF RATS SUBJECTED TO TOURNIQUET SHOCK AND TO TREATMENT WITH CARBON TETRACHLORIDE
}

\author{
BY ULRICH WESTPHAL, ROBERT DEARMOND, STANLEY G. PRIEST, AND \\ JOHN F. STETS
}

(From the Army Medical Research Laboratory, Fort Knox, Ky.)

(Submitted for publication July 28, 1952; accepted September 17, 1952)

The cause of a decreased azorubin-binding capacity $(A B C)$ of serum albumin, previously observed in humans under certain pathological conditions (1), is not known. The present paper is part of an experimental study into the mechanism of a lowering of the $\mathrm{ABC}(2)$. It describes the production of decreased $A B C$ values of serum albumin of rats by subjecting them to tourniquet shock or to treatment with carbon tetrachloride.

In addition, the serum protein composition of these experimental rats was analyzed, since changes in the protein metabolism have been observed in traumatic shock $(3,3 \mathrm{a})$.

\section{EXPERIMENTAL}

Chemical procedures. For the determination of the protein and non-protein nitrogen, the micro-Kjeldahl method of Hiller, Plazin, and van Slyke (4) was used, with some modifications which are described elsewhere (5). The non-protein nitrogen was separated from the serum proteins by precipitation with uranyl acetate according to the procedure of Neubauer (6). One ml. of serum was diluted with $3 \mathrm{ml}$. of water, and $1 \mathrm{ml}$. of 1.5 per cent uranyl acetate was added, with stirring, to the solution. The protein was filtered off after 60 minutes, using a Whatman No. 50 filter.

Since preliminary experiments indicated that a chemical determination of serum albumin with a 26.8 per cent sodium sulfate solution $(7,8)$ gave low values (for details see [5]), all albumin determinations were done by electrophoretic analysis.

Electrophoretic analysis. The veronal-acetate-sodium chloride buffer of Michaelis, $\mathrm{pH} 8.6, \mu=0.1$, was employed (9). Practically identical patterns were obtained in veronal buffer as used by Moore, Levin, and Leathem for rat sera (10). All $\mathrm{pH}$ measurements were done at room temperature with a glass electrode. The electrophoretic analyses were carried out in the compact Tiselius apparatus 1 (11), employing the Longsworth scanning mechanism and the $2 \mathrm{ml}$. cell in an open system. Some sera were also analysed in a standard size Tiselius electrophoresis apparatus ${ }^{2}$ using the long analytical cell (12);

\footnotetext{
1 Model 38 of the Perkin-Elmer Corporation, Glenbrook, Conn.

2 Frank Pearson Associates, New York 12, N. Y.
}

practically the same patterns and the same albumin percentages were obtained. The albumin concentrations were defined according to Wiedemann (13) and determined from both the descending and ascending boundaries. The globulin area was divided, by the method of Tiselius and Kabat (14), into three parts corresponding approximately to the alpha-, beta-, and gamma-globulin of human sera. More details on the electrophoretic analysis are given elsewhere (5).

For the electrophoretic analysis of normal rat serum in the presence of azorubin, a solution of $5 \mathrm{mg}$. purified azorubin (for purification see [15]) in $8 \mathrm{ml}$. buffer was added to $4 \mathrm{ml}$. of serum and dialysed. The buffers used were Michaelis buffer $\mathrm{pH} 8.6$ and phosphate buffers of $\mathrm{pH} 8.6,7.7,7.2$, and 6.1, $\mu=0.1$. The patterns were recorded on Kodak Ektachrome Color Film, using the optical system of Philpot-Svensson and a diagonal bar in the standard size electrophoresis apparatus.

Determination of $A B C$. The chromatographic method for estimating the $A B C$ (16) was modified so that only $1 \mathrm{ml}$. of serum was needed for the single chromatographic runs. A total of 4 or $3 \mathrm{ml}$. of serum was required, therefore, for each analysis, which consisted of a blank run and triplicate, or at least duplicate, runs of the serum-azorubin mixtures (see below). The chromatographic tubes employed were about $20 \mathrm{~cm}$. long, with an inner diameter of $5 \mathrm{~mm}$., and terminated in a $0.5 \mathrm{~mm}$. capillary of 2 to $3 \mathrm{~cm}$. length. A funnel was sealed to the upper end. The columns were formed using a slurry of $500 \mathrm{mg}$. of anionotropic aluminum oxide in freshly prepared, twice-distilled water. Methods for preparation and deactivation of anionotropic aluminum oxide have been described previously $(15,16)$. The length of the column obtained was about $25 \mathrm{~mm}$. The average total flow time for the serum-azorubin mixture described below was 9.5 minutes.

For each run, $1 \mathrm{ml}$. of serum and $0.25 \mathrm{ml}$. of an azorubin solution (mostly 0.5 per cent) in 0.6 per cent sodium chloride ( $\mathrm{pH} 7.8)$ were combined at least 30 minutes prior to the analysis. The azorubin concentration in the mixture should be at least twice as high as the "observed ABC" (see below). For the blank run, $0.25 \mathrm{ml}$. of 0.6 per cent sodium chloride was added to $1 \mathrm{ml}$. of serum. The mixtures were poured on the column immediately after the water (used to wash in the aluminum oxide) ceased to run out of the capillary. The first $1.0 \mathrm{ml}$. of the filtrate was discarded and 2 dilutions $(1: 20)$ of the last $0.25 \mathrm{ml}$. ( $\mathrm{pH} 6.1$ ) were made with $\mathrm{M} / 15$ phosphate 
buffer, pH $7.7(0.1 \mathrm{ml} .+1.9 \mathrm{ml}$. buffer $)$. The optical density was determined in a Coleman Junior Model 6A spectrophotometer at $515 \mathrm{~m} \mu$ using $10 \times 75 \mathrm{~mm}$. tubes. The azorubin concentrations were read in $\mathrm{mg}$. per cent from standard curves prepared as described elsewhere (15). The value obtained is the "ABC observed." This modified procedure has been found (15) to give the same results as the previous method (16).

The "specific ABC" was calculated in moles azorubin per gram of albumin, according to

$$
\mathrm{ABC}_{\text {spec. }}=\frac{\mathrm{ABC}_{\text {obs. }} \cdot 10^{-8}}{(0.8 \mathrm{C}-\mathrm{A}) 502}
$$

where $A B C_{\text {obs. }}=A B C$ observed, in mg. per cent;

$$
\begin{aligned}
\mathrm{C}= & \text { albumin concentration of serum, in } \\
& \text { grams per cent; } \\
\mathrm{A}= & 0.13 \text { for values of } \mathrm{C}>2.9 \% ; \\
& 0.12 \text { for values of } \mathrm{C}<2.9 \% .
\end{aligned}
$$

The correction factor " $A$ " accounts for the amount of albumin adsorbed by the aluminum oxide (see reference 15, Table 7). Studies on reproducibility and reliability of the chromatographic procedure for the estimation of the ABC have been described (15).

Animal experiments. Male Sprague-Dawley rats, fed on Purina Dog Chow checkers, were used. The average temperature of the animal room was about $24^{\circ} \mathrm{C}$. The rats were left without food and water for 24 hours before the experiments. Weights given were those of the fasted animals. Tourniquet shock was produced as in previous studies (17). The rubber bands were applied to both hind limbs for $4 \frac{1}{2}$ hours and the blood was drawn by heart puncture 3 hours after release of the tourniquets. The average yield per rat in "shock" was about $2 \mathrm{ml}$. of blood and $0.5 \mathrm{ml}$. of serum, whereas $6 \mathrm{ml}$. of blood and $2.2 \mathrm{ml}$. of serum were obtained from the normal rats.

The carbon tetrachloride (C. P. Medicinal) was injected intraperitoneally $(0.5 \mathrm{ml}$. per $\mathrm{kg}$. every second day for from 7 to 16 days) (18). Some rats that did not lose weight after several injections were then given intraperitoneal injections of a 1:1 mixture of carbon tetrachloride and 95 per cent ethanol $(1 \mathrm{ml} . / \mathrm{kg})$. The treatment with this solution (19) caused the weight of the animals to decline rapidly. The histological examination of the livers of a number of rats showed toxic degenerative changes which were consistent with the known picture of carbon tetrachloride poisoning. The amounts of blood and serum obtained from the carbon tetrachloride-treated rats were approximately the same as those from normal animals. Since the amount of serum obtained from one rat was not sufficient for the various analyses, pooled samples were used in all groups, as indicated in Table I.

\section{RESULTS}

The electrophoretic analysis of normal rat sera in the presence of azorubin demonstrated that this
TABLE I

Azorubin-binding capacity $(A B C)$ of serum albumin of normal, shocked, and carbon tetrachloride-treated rats

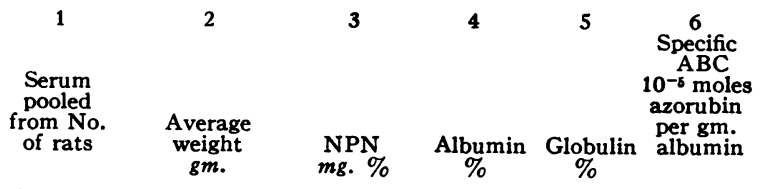

A. Normal Rats

$\begin{array}{cccccc}6 & 396 & 38.3 & 4.06 & 2.25 & 2.38 \\ 4 & 411 & 37.8 & 3.74 & 3.07 & 2.66 \\ 4 & 408 & 30.0 & 3.97 & 2.85 & 2.24 \\ 3 & 389 & 35.3 & 3.29 & 3.23 & 2.45 \\ 4 & 280 & 33.3 & 4.33 & 2.33 & 2.20 \\ 4 & 255 & 38.0 & 4.07 & 2.65 & 2.96 \\ \text { Average } & & & & & \\ \text { Values* } & 357 & 35.5 & 3.91 & 2.73 & 2.48\end{array}$

B. Rats Subjected to Tourriquet Shock

$\begin{array}{crrrrr}8 & 365 & 70.0 & 3.97 & 2.97 & 2.02 \\ 13 & 344 & 75.5 & 4.84 & 2.02 & 1.70 \\ 13 & 322 & 78.5 & 3.36 & 3.15 & 2.17 \\ 23 & 266 & 83.5 & 3.17 & 2.26 & 1.83 \\ 12 & 276 & 84.5 & 3.56 & 2.01 & 1.80 \\ 11 \dagger & 346 & 138.0 & 4.08 & 2.89 & 1.33 \\ \text { Average } & & & & & \\ \text { Values* } & 313 & 78.4 & 3.78 & 2.48 & 1.91\end{array}$

C. Rats Treated with Carbon Tetrachloride

$\begin{array}{clllll}4 & 317 / 248 \ddagger & 41.8 & 3.16 & 3.03 & 1.40 \\ 4 & 318 / 264 & 43.5 & 3.09 & 2.58 & 1.91 \\ 5 & 314 / 223 & 46.5 & 3.07 & 2.64 & 2.04 \\ 4 & 292 / 251 & 43.0 & 3.69 & 2.48 & 1.72 \\ 4 & 310 / 241 & 49.0 & 3.01 & 2.27 & 1.85 \\ 5 & 307 / 270 & 48.8 & 2.88 & 1.99 & 1.27 \\ 4 & 345 / 305 & 43.8 & 3.84 & 2.87 & 1.43 \\ \text { Average } & & & & & \\ \text { Values* } & 315 / 257 & 45.2 & 3.25 & 2.55 & 1.66\end{array}$

* All average values were calculated as arithmetical means of the figures obtained, not considering the varying number of animals in the groups.

† Tourniquets applied unilaterally to the left fore and hind legs for 5 hours, blood drawn 17 hours after removal. Not included in average values.

$\ddagger$ Weights before and after treatment.

dye is bound exclusively to the albumin component, at $\mathrm{pH}$ values between 6.1 and 8.6.

The results of the serum analysis and the $A B C$ values are given in Table $I$. The average specific $A B C$ values of the serum albumin of the shocked and carbon tetrachloride-treated rats were 23 per cent and 33 per cent, respectively, lower than those of the normal controls. In one group of rats which were subjected to more severe conditions of tourniquet shock, a 46 per cent decrease of the $\mathrm{ABC}$ was observed.

Table II shows the percentage values of the electrophoretic protein components for the three series of rats. 
TABLE II

Electrophoretic analysis of serum proteins of normal, shocked, and $\mathrm{CCl}_{1}$-treated rats

Protein components in per cent of total protein

\begin{tabular}{|c|c|c|c|c|c|}
\hline \multirow{2}{*}{$\begin{array}{c}\text { Rats, } \\
\text { treatment }\end{array}$} & \multirow{2}{*}{$\begin{array}{c}\text { Total } \\
\text { protein } \\
\%\end{array}$} & \multirow[b]{2}{*}{ Albumin } & \multicolumn{3}{|c|}{ Globulin } \\
\hline & & & Alpha & Beta & Gamma \\
\hline $\begin{array}{l}\text { Normal } \\
\text { Normal } \\
\text { Normal } \\
\text { Normal } \\
\text { Normal } \\
\text { Normal } \\
\text { Average }\end{array}$ & $\begin{array}{l}6.31 \\
6.81 \\
6.82 \\
6.52 \\
6.66 \\
6.72\end{array}$ & $\begin{array}{l}63.9 \\
54.9 \\
58.2 \\
50.4 \\
65.0 \\
60.6 \\
58.9\end{array}$ & $\begin{array}{r}9.9 \\
10.1 \\
14.6 \\
18.6 \\
12.6 \\
8.2 \\
12.3\end{array}$ & $\begin{array}{l}17.3 \\
22.1 \\
17.9 \\
20.3 \\
14.9 \\
15.1 \\
17.9\end{array}$ & $\begin{array}{r}8.9 \\
12.9 \\
9.3 \\
10.7 \\
7.5 \\
16.1 \\
10.9\end{array}$ \\
\hline $\begin{array}{l}\text { Tourniquet Shock } \\
\text { Tourniquet Shock } \\
\text { Tourniquet Shock } \\
\text { Tourniquet Shock } \\
\text { Tourniquet Shock } \\
\text { Tourniquet Shock } \\
\text { Average }\end{array}$ & $\begin{array}{l}6.94 \\
6.97 \\
6.86 \\
6.51 \\
5.43 \\
5.57 \\
6.38\end{array}$ & $\begin{array}{l}\mathbf{5 7 . 2} \\
58.5 \\
70.6 \\
51.6 \\
58.4 \\
63.8 \\
60.0\end{array}$ & $\begin{array}{r}8.7 \\
16.1 \\
8.2 \\
10.2 \\
13.0 \\
11.4 \\
11.3\end{array}$ & $\begin{array}{l}23.5 \\
19.3 \\
17.0 \\
23.0 \\
19.2 \\
16.2 \\
19.7\end{array}$ & $\begin{array}{r}10.6 \\
6.1 \\
4.2 \\
15.2 \\
9.4 \\
8.6 \\
9.0\end{array}$ \\
\hline $\begin{array}{l}\mathrm{CCl}_{4} \text {-Treatment } \\
\mathrm{CCl}_{4} \text {-Treatment } \\
\text { CCl-Treatment } \\
\mathrm{CCl}_{4} \text {-Treatment } \\
\text { CCl-Treatment } \\
\text { CCl-Treatment } \\
\text { CCl} \text {-Treatment } \\
\text { Average }\end{array}$ & $\begin{array}{l}6.19 \\
5.67 \\
5.71 \\
6.17 \\
5.28 \\
4.87 \\
6.71 \\
5.80\end{array}$ & $\begin{array}{l}\mathbf{5 1 . 1} \\
\mathbf{5 4 . 5} \\
\mathbf{5 3 . 8} \\
\mathbf{5 9 . 8} \\
\mathbf{5 6 . 9} \\
\mathbf{5 9 . 2} \\
\mathbf{5 7 . 3} \\
\mathbf{5 6 . 1}\end{array}$ & $\begin{array}{l}22.1 \\
19.5 \\
24.9 \\
17.3 \\
14.8 \\
14.6 \\
16.0 \\
18.5\end{array}$ & $\begin{array}{l}19.7 \\
16.6 \\
15.3 \\
16.7 \\
19.2 \\
18.4 \\
18.4 \\
17.7\end{array}$ & $\begin{array}{l}7.1 \\
9.4 \\
6.0 \\
6.2 \\
9.1 \\
7.8 \\
8.3 \\
7.7\end{array}$ \\
\hline
\end{tabular}

\section{DISCUSSION}

Analyzing the data of Table II, it should be pointed out that the electrophoretic analysis of the rat sera did not result in patterns in which the different globulin components were as distinct as generally seen with human sera. This is in accordance with observations of Gjessing and Chanutin (20). The separation of the globulin area into the three components is, therefore, rather arbitrary, even more than in the differentiation of the globulins in human sera (21).

In spite of this limitation, Table II shows that subjecting rats to tourniquet shock, under the conditions described, did not change markedly the concentration of albumin or of the globulin components in the serum. The results did not indicate any shift of serum albumin from the circulating blood into the injured tissues as demonstrated by a different experimental procedure by Moore and his associates in mice (22) and dogs (23) in traumatic shock. The electrophoretic patterns of the sera of "shocked" rats (Table II) did not reveal the appearance of increased quantities of a protein with a mobility similar to gamma-globulin as observed in mice under certain conditions of severe traumatic shock (22).
The average absolute and relative albumin values of the carbon tetrachloride-treated rats were lower than those obtained in the normal animals. A slight increase in the average alpha-globulin value was obtained in the rats that received carbon tetrachloride. High values of this globulin component have been found under various pathological conditions in several species, among others in injured rats (20).

The specific $A B C$ values were determined on the basis of the finding that azorubin is bound exclusively to albumin in rat serum. A similar result was obtained previously with human serum $(1,16)$. Assuming a molecular weight for rat serum albumin similar to that of human albumin, 1 mole of serum albumin of normal rats was found to bind 1.71 moles of azorubin; the values for "shocked" rats were 1.32 and 0.92 moles, depending on the severity of the shock produced. In the serum of carbon tetrachloride-treated rats, 1.14 moles of azorubin were bound per mole albumin. It may be pointed out in this connection that the average specific $A B C$ value obtained with the chromatographic procedure in humans was 5.8 moles of azorubin per mole of albumin in normal persons, whereas values down to about 1 mole were observed in pathological cases (1).

The present studies demonstrate that it is possible to lower experimentally the $A B C$ of serum albumin in rats. This decrease of the specific $A B C$ values is considered to be typical of the albumin of the experimental rats, and not to be caused by a lower concentration of "normal" albumin in the treated animals. Previous studies on the chromatographic method have shown (16) that the specific $A B C$ value of a given serum albumin is lowered by an extreme reduction of the albumin concentration of the test solution. However, an investigation into the quantitative side of this effect (see reference 15, Fig. 2) has shown that the specific $A B C$ value of a 3.25 per cent solution of human albumin is less than 0.2 per cent lower than that of a 3.91 per cent solution of the same albumin. Assuming the binding of azorubin to rat serum albumin and that to human serum albumin to be essentially similar, a difference of about 0.2 per cent would be expected between the specific $A B C$ values of the sera of normal and those of carbon tetrachloride-treated rats (albumin concentration 3.91 and 3.25 per cent, re- 
spectively, see Table I), if such a difference were caused solely by the concentration effect described above. It seems improbable, therefore, that decreases in the specific ABC 100 to 200 times as great $(23,33$ or 46 per cent) as observed between the normal and experimental groups (Table I) could be explained on the basis of differences in the albumin concentrations.

The degree of decrease in the specific $A B C$ values of the "shocked" rats was proportional to the severity of their condition (Table I, last group of "shocked" rats compared to the other groups). Analyzing the single data of all groups of rats studied (Table I), no proportionality was found between albumin concentration and the degree of lowering of the specific $A B C$ values. These observations are considered to be additional evidence for the conclusion that the albumin concentration does not play an essential role in the lowering of the specific $A B C$ values obtained in the experimental animals. Disregarding the species difference, this is in contrast to the claim of Bennhold, Ott, and Kallee (24) that a decrease in the specific $A B C$ values of human sera is caused exclusively by a reduced albumin concentration.

An analysis of the mechanism of a lowering of the $\mathrm{ABC}$ of serum albumin is believed to be of interest since a decrease in the $\mathrm{ABC}$ is considered to be but one example of the general phenomenon of a lowered capacity of serum albumin to bind anions. Decreased binding values of serum albumin for another anion, phenolsulfonephthalein, have been observed in cancer patients (25) and in pregnant women (26).

It is believed by the present authors that the decrease in the ABC of serum albumin, observed in different species under various conditions, is not caused by chemical differences in the albumin molecules, but rather by the binding of certain anions, e.g., fatty acids, to the albumin. A firm binding of such anions would block the binding sites for azorubin and thus reduce the ABC. This conclusion is based on the following findings:

No proportionality was observed between the specific $A B C$ values of the albumin fractions isolated by the cold alcohol fractionation procedure from sera giving normal and sera giving decreased specific $A B C$ values. No chemical differences in the protein composition were observed either be- tween the albumin fractions obtained from normal $A B C$-sera and those from low ABC-sera (1). The significance of these negative results is limited, however, since alterations during the preparation of the albumin fractions cannot be excluded.

Any degree of decrease in the specific $A B C$ of serum albumin could be produced by addition of various amounts of certain fatty acids and other anions to albumin solutions and normal sera (2). This effect was exerted by very small amounts of anions, e.g., one mole of myristic acid per mole of human albumin decreased its specific ABC by 26 per cent, and 5 moles of stearic acid per mole of albumin lowered the $\mathrm{ABC}$ value of a human serum by about 30 per cent. It may be noted that in all these experiments the albumin concentrations of the test solutions containing the anions were equal to those of the control solutions.

Experiments are in progress to find out whether the albumin present in low ABC-sera contains greater amounts of firmly bound anions (higher fatty acids?) than that present in normal sera. The results of these studies may aid in an understanding of the relationship between the decreased specific $A B C$ values and the pathological conditions under which they occur.

\section{SUM MARY}

1. The protein composition of the serum of rats subjected to tourniquet shock was found not to be significantly different from that of normal rats. Administration of carbon tetrachloride caused a slight elevation of the serum alphaglobulin level, and some decrease in the average albumin concentration.

2. Electrophoretic studies demonstrated that in rat serum the anionic dye azorubin is bound exclusively to albumin.

3. The azorubin-binding capacity of serum albumin of rats was decreased in tourniquet shock and after treatment with carbon tetrachloride.

4. This lowering of the specific azorubin-binding capacity was not caused by and not related to a decrease in the albumin concentration.

5. A possible mechanism of a decrease in the azorubin-binding capacity of serum albumin is suggested. 


\section{REFERENCES}

1. Westphal, U., and Gedigk, P., Azorubin-binding capacity of normal and pathological sera. Proc. Soc. Exper. Biol. \& Med., 1951, 76, 838.

2. Westphal, U., DeArmond, R., Priest, S. G., and Stets, J. F., Azorubin-binding capacity of serum albumin of rats subjected to tourniquet shock and $\mathrm{CCl}_{4}$-poisoning. Federation Proc., 1952, 11, 309.

3. Selye, H., The physiology and pathology of exposure to stress; a treatise based on the concepts of the general-adaptation-syndrome and the diseases of adaptation. Montreal, Acta, 1950, p. 163.

3a. Wiggers, C. J., Physiology of Shock. New York, Commonwealth Fund, 1950, p. 352.

4. Hiller, A., Plazin, J., and van Slyke, D. D., A study of conditions for Kjeldahl determination of nitrogen in proteins. Description of methods with mercury as catalyst, and titrimetric and gasometric measurements of the ammonia formed. J. Biol. Chem., 1948, 176, 1401.

5. *Westphal, U. F., Priest, S. G., and Stets, J. F., Azorubin-binding capacity of serum albumin of rats subjected to tourniquet shock and to treatment with carbon tetrachloride. Army Medical Research Laboratory Report No. 76, 15 February 1952.

* This report may be obtained on request.

6. Hallmann, L., Klinische Chemie und Mikroskopie, Stuttgart, Thieme, 1948, 5. Aufl., p. 365.

7. Majoor, C. L. H., The possibility of detecting individual proteins in blood serum by differentiation of solubility curves in concentrated sodium sulfate solutions. II. Comparison of solubility curves with results of electrophoresis experiments. J. Biol. Chem., 1947, 169, 583.

8. Milne, J., Serum protein fractionation: A comparison of sodium sulfate precipitation and electrophoresis. J. Biol. Chem., 1947, 169, 595.

9. Wiedemann, E., Electrophorese-Versuche an Serum und Plasma. Schweiz. med. Wchnschr., 1946, 76, 241.

10. Moore, D. H., Levin, L., and Leathem, J. H., The alpha-globulin fraction of the serum of normal and hypophysectomized rats. J. Biol. Chem., 1944, 153, 349.

11. Moore, D. H., and White, J. U., A new compact Tiselius electrophoresis apparatus. Rev. Scient. Instruments, 1948, 19, 700.

12. Longsworth, L. G., Recent advances in the study of proteins by electrophoresis. Chem. Rev., 1942, 30, 323.

13. Wiedemann, E., Ueber die Auswertung von Elektrophorese-Diagrammen nach L. G. Longsworth and
Philpot-Svensson. Helvet. Chim. Acta., 1947, 30, 892.

14. Tiselius, A., and Kabat, E. A., An electrophoretic study of immune sera and purified antibody preparations. J. Exper. Med., 1939, 69, 119.

15. *Westphal, U. F., Priest, S. G., and Stets, J. F., A modified method for the determination of the azorubin-binding capacity of albumin in small amounts of serum. Army Medical Research Laboratory Report No. 63, 4 September 1951.

* This report may be obtained on request.

16. Westphal, U., Gedigk, P., and Meyer, F., Ueber eine chromatographische Methode zur Charakterisierung von Serumeiweiss. Ztschr. f. physiol. Chem., 1950, 285, 36.

17. Westphal, U., Kocholaty, W., McDonald, B., King, E., and Jensen, H., Studies on proteolytic, fibrinolytic, antitryptic and antifibrinolytic activities in the blood of rats. Proc. Soc. Exper. Biol. \& Med., 1950, 75, 862.

18. Brauer, R. W., and Root, M. A., The effect of carbon tetrachloride-induced liver injury upon the acetylcholine hydrolyzing activity of blood plasma of the rat. J. Pharmacol. \& Exper. Therap., 1946, 88, 109.

19. Gonzalez-Oddone, M. V., Studies of the thoracic duct lymph in experimental liver injury in dogs. Proc. Soc. Exper. Biol. \& Med., 1946, 63, 540.

20. Gjessing, E. C., and Chanutin, A., An electrophoretic study of plasma and plasma fractions of normal and injured rats. J. Biol. Chem., 1947, 165, 657.

21. Longsworth, L. G., Shedlovsky, T., and MacInnes, D. A., Electrophoretic patterns of normal and pathological human blood serum and plasma. J. Exper. Med., 1939, 70, 399.

22. Moore, D. H., and Fox, C. L., Correlation of electrophoretic studies and other factors in the syndrome of secondary shock. Nature, London, 1950 , $165,872$.

23. Moore, D. H., Nickerson, J. L., Powell, A. E., and Marks, G., A study of the transfer of serum proteins into tissue injured by tourniquet. Proc. Soc. Exper. Biol. \& Med., 1951, 77, 706.

24. Bennhold, H., Ott, H., and Kallee, E., Ueber die Azorubin-bindung an Humanserum. Ztschr. f. physiol. Chem., 1951, 287, 185.

25. Huggins, C., Jensen, E. V., Player, M. A., and Hospelhorn, V. D., The binding of phenolsulfonephthalein by serum and by albumin isolated from serum in cancer. Cancer Research, 1949, 9, 753.

26. Miller, G. H., Davis, M. E., King, A. G., and Huggins, C. B., Serum proteins in pregnancy. J. Lab. \& Clin. Med., 1951, 37, 538. 